\title{
Internet of Things Business Models
}

\author{
Hubert C. Y. Chan \\ The Hong Kong Polytechnic University, Hong Kong, China \\ Email: hubertchan@hkc.net
}

Received 12 June 2015; accepted 9 August 2015; published 12 August 2015

Copyright (C) 2015 by author and Scientific Research Publishing Inc.

This work is licensed under the Creative Commons Attribution International License (CC BY). http://creativecommons.org/licenses/by/4.0/

(c) (i) Open Access

\begin{abstract}
Almost all businesses are aware of the potential gains that the Internet of Things (IoT) has to offer, they are unsure of how to approach it. This article proposes a business model that builds on Holler et al., (2014) [1]. The model consists of three dimensions: "Who, Where, and Why". "Who" describes collaborating partners, which builds the "Value Network". "Where" describes sources of value co-creation rooted in the layer model of digitized objects, and "Why" describes how partners benefit from collaborating within the value network. With the intention of addressing "How", the proposed framework has integrated the IoT strategy category, tactics, and value chain elements. The framework is then validated through the case studies of some successful players who are either the Awardees of the IoT Award 2014 or the ICT Award 2015 of Hong Kong.
\end{abstract}

\section{Keywords}

\section{Internet of Things (IoT), Business Model, Strategy and Tactic in IoT, Case Studies in IoT}

\section{Introduction}

Internet of Things (IoT) is an integrated part of Future Internet. According to the agreed protocol, any article can be connected and talk to each other. This can be achieved through a vast number of methods and technologies, including radio frequency identification (RFID), near field communication (NFC), infrared (IR) sensors, and many more. The IoT paradigm is a result of the convergence of three main visions: internet-oriented (middleware), things oriented (sensors) and semantic-oriented (knowledge) (Abdmeziem and Tandjaoui, 2014) [2]. Although common protocol for communication between smart objects still does not exist yet, IoT will change the world as we know it; according to the GSMA (2014, p. 3) [3]. The number of global machine-to-machine (M2M) connections reached 195 million in 2013, with a growth rate of nearly 40\% between 2010 and 2013. It is estimated by Gubbi et al., (2013) [4] that by 2020, the number of interconnected devices will reach 24 billion. This will allow for automation in nearly every industry, with notable applications in healthcare, home automation, utility management, traffic management, and ultimately a Smart City. 
Physical objects gain characteristics of digital technology with the addition of a digital aspect (Yoo et al., 2010) [5]. As such, physical objects are then capable of being programmable, addressable, communicable, and sensible. The nature of combining digital technology with physical objects often results in collaborations between partners of vastly different industries (Turber et al., 2014) [6]. Firms are not only selling goods to buyers, but also providing platforms upon which users can add value upon. However, the identification of the killer application and the definition of the underlying business model are still missing (Atzori, Iera, \& Morabito, 2014) [7]. Filling in this gap, the objectives of this article are to identify the killer applications or the value proposition, and evaluate the business models through the case studies of some successful players who are either the Awardees of the IoT Award 2014 organized by GS1 (HK) or the ICT Award 2015 through interviews or secondary data. An IoT business model framework is proposed for this purpose.

\section{IoT Business Model Framework Review}

Business model is defined as the plan implemented by a company to generate revenue and make a profit from operations (Investopedia n.d., "Business Model") [8]. That being said, it is clear that a company that lacks a clear and organized plan to generate profit and revenue will likely be unsuccessful. Traditional business models are designed on a firm-centric basis; however due to the nature of the IoT ecosystem in which firms must collaborate with competitors and across industries, it is easy to see why traditional business models are not adequate. Moreover, fast changing market environments in technology-related industries implies that companies must quickly adjust to market challenges in order to succeed. As a result, business model innovations are becoming "new routes to competitive advantage" (Sun et al., 2012) [9]. Bucherer et al., (2012) [10] described some key issues when designing IoT business models, including "information between nodes and win-win information exchange for all stakeholders". Furthermore, Westerlund et al., (2014) [11] identified three contemporary challenges of the IOT, comprising the diversity of objects, the immaturity of innovation, and the unstructured ecosystems. The diversity of objects refers to a multitude of different types of connected objects and devices without commonly accepted or emerging standards. Immaturity of innovation refers to today's quintessential IOT innovations have not yet matured into products and services. Unstructured ecosystems refer to the lack of defined underlying structures and governance, stakeholder roles, and value-creating logics. Despite of these challenges, several IoT business model frameworks exist, but there are still some major gaps in the IoT that need to be properly addressed.

Business models consist of several essential elements: "Who, What, How, and Why” (Gassmann et al., 2014) [12]. "Who" refers to the target customer, "What" is the value proposition that is offered to the customer, "How" is the value chain to deliver the value proposition to the customer, and "Why" describes the underlying economic model to capture value. These four essential elements in Figure 1 must be addressed for a business model to be functional. This is the fundamental requirement in building our proposal.

As value creation in traditional product mindset shifts from solving existing needs in a reactive manner to ad-

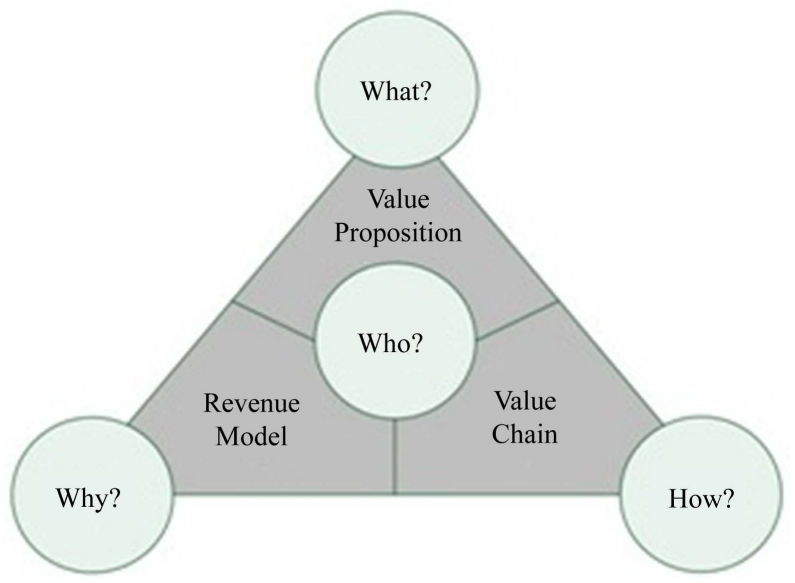

Figure 1. "The archetypal business model” (Gassman, Frankenberger, \& Csik, 2014) [12]. 
dress real-time and emergent needs in a predictive manner, filling out well-known frameworks and streaming established business models will not be enough (Hui, 2014) [13]. Value creation in IoT can be classified into three layers (Mejtoft, 2011) [14]: manufacturing, supporting, and value creation. Manufacturing layer means that manufacturers or retailers can provide items such as sensors and terminal devices. Supporting layer collects data which can be utilized in the value creation processes, while the third layer uses IoT as a co-creative partner, because the network of Things can think for itself. Chen Min (2013) [15] presents a more detail four-layer architecture for Internet of Things (IoT) as shown in Figure 2:

- Object sensing and information gathering: The first step of enabling smart services is to collect contextual information about environment, "things" and objects of interest.

- Information delivering: Various wireless technologies such as wireless sensor networks (WSNs), body area networks (BANs), WiFi, Bluetooth, Zigbee, GPRS, GSM, cellular and 3G, etc. can be used for delivering the information.

- Information processing: Pervasive and autonomic services are provided through ubiquitous machines in both "autonomic" and "smart" way.

- Application and smart services: Heterogeneous network performance in terms of bandwidth utilization, computing capability and energy efficiency are improved according to different users' requirements, and application-specific design.

Each company can participate into more than one layer, and create its own business model.

Leminen et al., (2012) [16] posited that the central elements of IOT include the concepts of "the ecosystem", "the ecosystem core", and "the business model". They built a framework connecting the types of IoT business models with the underlying ecosystems. The framework uses the type of ecosystem (closed private or open networked) and the type of customers (business and consumers) as two principle axes as depicted in Figure 3. The authors used case examples from automotive industry as illustrations: Intelligent logistics in the future car production and logistics for model I; Current RFID usage in car production and logistics for model II; Traffic safety services for model III; and Tracking and tracing in car logistics for model IV.

The degree of openness is dependent on the maturity of the ecosystem. Rong, et al., (2015) [17] developed an integrated 6C framework in order to improve systematic understanding of the IoT based business system, namely Context, Cooperation, Constructive elements, Configuration, Capability, and Change. The context is the environmental settings for the ecosystem development. The cooperation reflects the mechanism by which the partners interact in order to reach the strategic objectives. Constructive elements define the fundamental structure and supportive infrastructure of the ecosystem. Configuration seeks to identify the external relationships among partners. Capacity investigates the key success features of a supply network from the functional view of design, production, inbound logistics and information management. Finally, each business ecosystem faces the challenge of change. Their case studies revealed that the ecosystem is very open at an early stage where the focal firm needs more stakeholders to add value to the product platform. The focal firm is mainly able to control product deve-

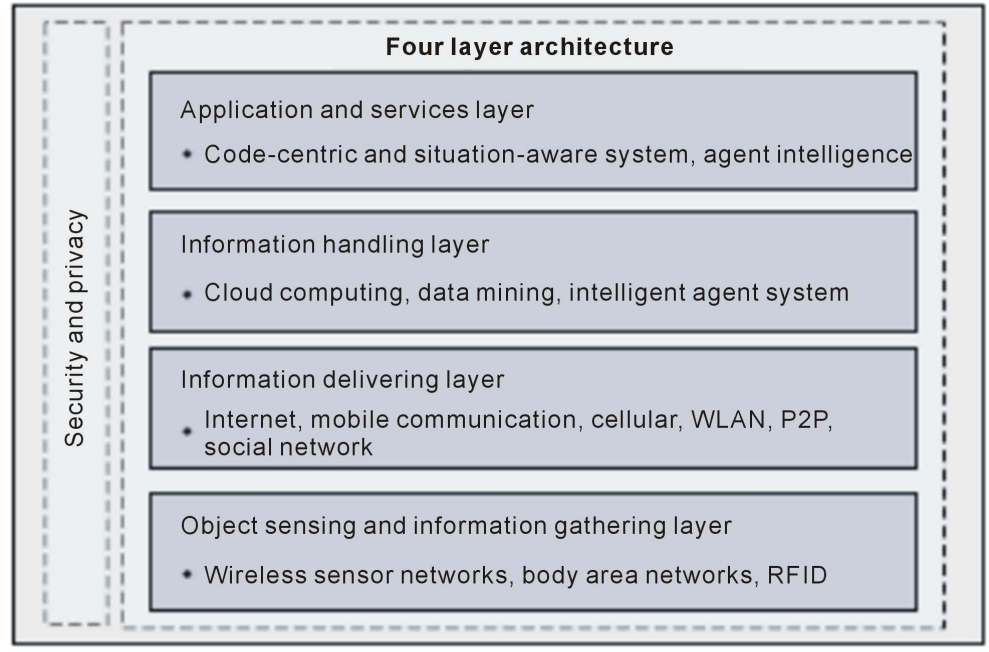

Figure 2. Architecture for Internet of Things (Chen Min, 2013) [15]. 


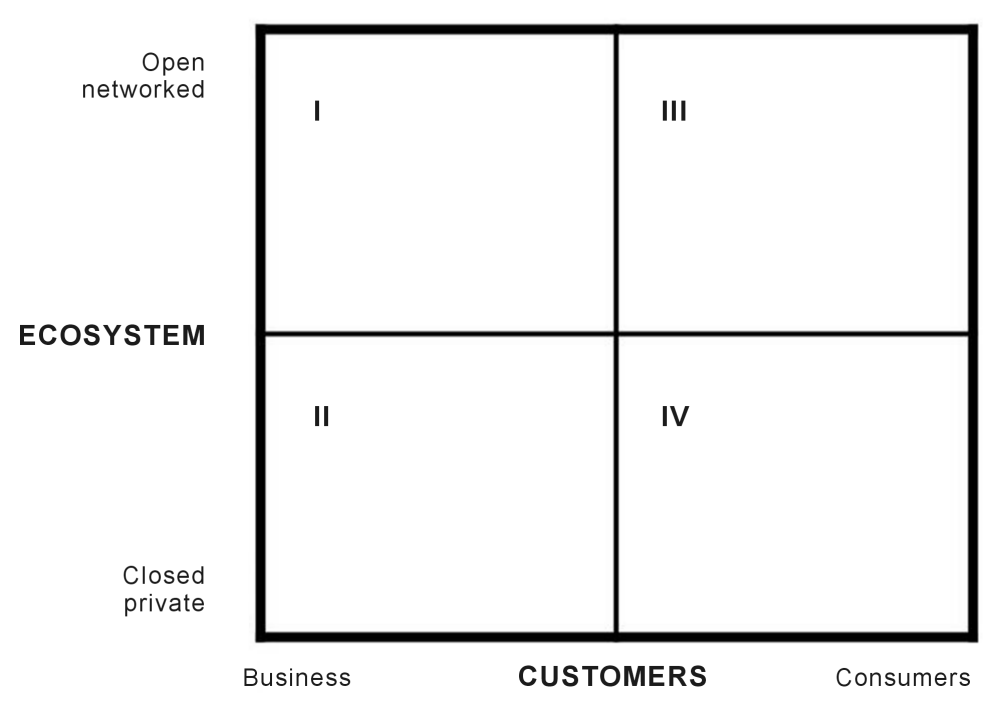

Figure 3. Framework for analyzing diverse IoT business model (Leminen et al., 2012) [16].

lopment but still welcomes customers and third parties to modify the incomplete product and refine it with more functional features once the ecosystem begins to mature. As the ecosystem becomes very mature, the focal firm will consider the product as a dominant design and get feedback from customers and no access points for customer to change the products. They suggested the development of any new business model should be adaptable via an open platform and diverse solutions to allow participants' resources and capabilities to be fully utilized.

Sun et al., (2012) [9] posited a DNA model addressing the "How, What, and Why" elements of IoT business model. There are three blocks: D-design, N-needs, and A-aspirations. Design consists of the various elements of the system such as key partners, resources, and activities. This deals with the "How" question of business models. Needs refer to parties in the "external environment" such as customer segments and relationships, dealing with "What". Aspirations are desired results such as revenue, and deals with "Why". The authors used smart logistic as an illustration: In Design, the key partners are those enterprises that produce food, books, e-products, clothes and so on. The data processing center and the transport fleet are the key resources; In Needs, there are many channels to reach customers such as the Internet, a mobile network, or just through the retail stores. Customer relationships can be long term or just temporary. Customers (individuals or companies) can become participants or recipients; In Aspiration, the value proposition is to achieve better meet customer demand. The DNA model is a linear fractal showing the cause-and-effect or input-processing-output relationship. However, the "How, What, and Why" of each individual collaborator cannot be clearly distinguished.

But in a connected world, products are no longer one-and-done in a connected world. New features and functionality can be pushed to the customer on a regular basis. Customer behavior can be tracked, and products can now be connected with other products, leading to new analytics and new services for more effective forecasting, process optimization, and customer service experiences (Hui G., 2014) [13]. Thus, it is more appropriate to use Service-Dominant (S-D) logic to construct the business model for IoT (Turber et al., 2014) [6]. Under S-D logic, it is believed that IoT firms will no longer simply be selling goods to the customer, but will be acting as platforms for customers and competitors adding value upon. In S-D logic, the traditional firm-centric view is replaced by a network-centric view. Individual firms must work with market partners and customers to create "value creation networks", in which individual firms act as "organizers of value creation". Individual firms must be capable of making smart collaborations, as collaborations form the fundamental basis of the Internet of Things. If a firm is unable or unwilling to be collaborative, it will not be competitive.

The focus shifts to other business model parameters as the service content increases particularly in IoT markets. Kindström D. (2010) [18] outlined the key aspects of a service based business model together with associated key issues as depicted in Table 1. In additional to "What" (value proposition), "Why" (revenue mechanism), "How" (value Chain), and "Who" (target market), there are two elements, namely the "Value network", and "Competitive Strategy". This aligns with the emphasis of network-centric view in IoT business model. 
Table 1. Service based business model parameters (Kindström D., 2010) [18].

\begin{tabular}{|c|c|}
\hline Business model parameter & Key issues \\
\hline Value proposition & $\begin{array}{l}\text { - } \text { Articulated offering } \\
\text { - } \quad \text { Visualization } \\
\text { - } \quad \text { A dynamic offering portfolio }\end{array}$ \\
\hline Revenue mechanisms & - New revenue model \\
\hline Value chain & $\begin{array}{l}\text { - } \quad \text { Dedicated roles for service development } \\
\text { - A structured service development process } \\
\text { - A new reward system } \\
\text { - Extending the resource base }\end{array}$ \\
\hline Value network & - Finding partners that can add value to the new offerings \\
\hline Competitive strategy & $\begin{array}{ll}\text { - } & \text { Branding } \\
\text { - } & \text { Differentiation }\end{array}$ \\
\hline Target market & - New customer segmentation \\
\hline
\end{tabular}

Turber et al., (2014) [6] posited that a business model framework in IoT consists of three dimensions: "Who, Where, and Why". "Who" describes collaborating partners, who build the "Value Network", and does not only include firms who create IoT products, but also includes customers and stakeholders to reflect the networkcentric sentiment that customers are co-creators and co-producers of value. "Where" describes sources of value co-creation rooted in the layer model of digitized objects. There are four places of opportunity for value to be added by the collaborators. They are the device, connectivity, service and content layer (Yoo et al., 2010) [5]. The device layer comprises hardware, and an operating system; the network layer involves transmission plus network standard, and physical transport; the service layer provides direct interaction with users through application programs; while the content layer hosts the data, images and information. "Why" describes the benefits for partners from collaborating within the value network, both monetary benefits and non-monetary benefits as shown in Figure 4. Each dimension addresses the four-layered modular architecture of digitized products.

Westerlund et al., (2014) [11] provided three pillars for designing ecosystem business models required in the IOT context, namely the drivers, value nodes, exchanges, and extracts of value. Divers comprise both individual and shared motivations of diverse participants who fulfill a need to generate value, realize innovation, and make money in an ecosystem. Value nodes include various actors, activities, or (automated) processes that are linked with other nodes to create value. Value exchange refers to an exchange of value by different means, resources, knowledge, and information between and within different value nodes. Value extracts refers to part of ecosystem that extracts value or be monetized. These pillars are interconnected, and, in contrast to existing business model frameworks, they aim to explain the flows and action of a business model rather than components of the model. In fact, the "Who" the framework of Holler et al., (2014) [1] are the drivers articulated by Westerlund et al., (2014) [11], the "What "reflects the value nodes, while the "Why" refers to the value extracts. However, the "How" that is the value exchange is not explicitly revealed.

\section{Framework Development}

In the review of the contemporary business models in IoT, the framework posited by Holler et al., (2014) [1] is the most comprehensive one, except the "Competitive Strategy" and "How" (value chain) elements need to be expanded as suggested in Table 1. Strategy refers to the choice of business model through which the firm will compete in the marketplace. Business Model refers to the logic of the firm, the way it operates and how it creates value for its stakeholders. Tactics refers to the residual choices open to a firm by virtue of the business model it chooses to employ. We are going to explore how these elements to be incorporated into our proposed framework.

\subsection{Competitive Advantage}

Competitive Advantage can be gained with an effective strategy in grasping the emerging opportunities from 


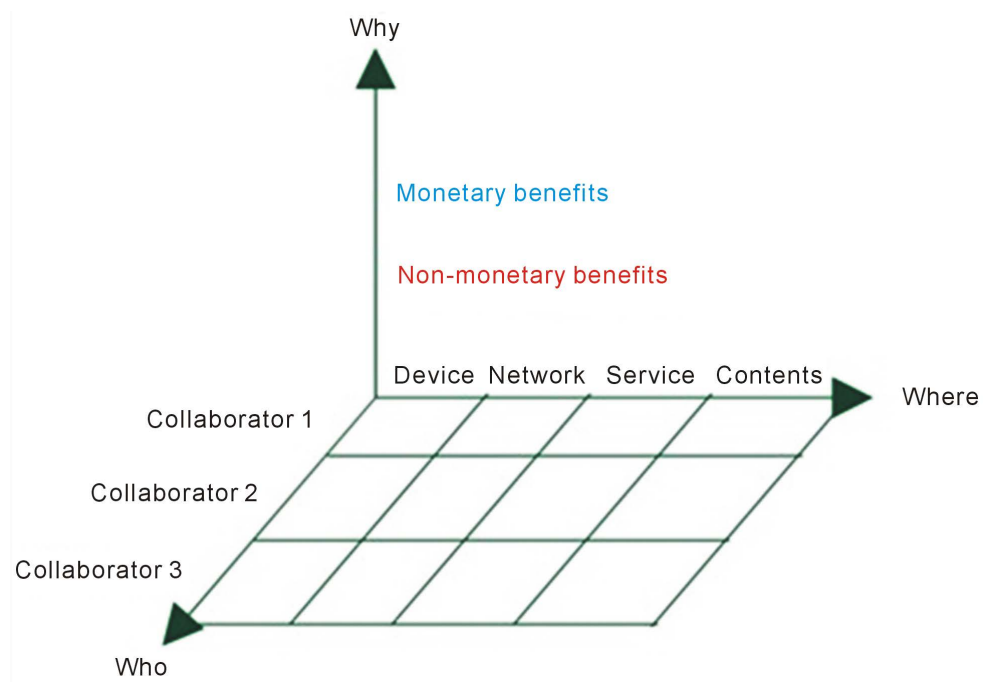

Figure 4. Framework design for a business model framework in the IoT context (Turber et al. 2014 p. 24) [6].

IoT. Li et al., (2012) [19] proposed four categories of IoT strategies, as illustrated in Table 2: get-ahead strategy in market, catch-up strategy in market, get-ahead strategy in technology, and catch-up strategy in technology. Technology push is applying new technology to IoT application while market pull is the demand in response to an identified and potential market need. Get-ahead strategy is a set of plans \& action to enable the firm to stay head of other competitors so as to enjoy the first-mover advantages, whereas catch-up strategy is a set of plans and action following and learning from the industrial leaders' movements through operational efficiency and quality. The authors listed an example in each category as illustrations: Haier, which is a leading home appliance manufacturer in China, is facilitated to use IoT technologies in their products to fulfill the increasing demand for smarter appliances in the Get-ahead strategy in market; local supermarkets learning from Wal-mart to improve the efficiency of their logistics, orders, and sales by adopting of IoT technologies in the Catch-up strategy in market; Cinterion, which is a supplier of wireless modules for the cellular Machine to Machine (M2M) communication, has successfully turned itself to be the world's leading player in this arena and enjoys a prestigious position among competitors in the Get-ahead strategy in technology; Junmp, which is a RFID technology provider in China, produces RFID labels and readers through a cooperation agreement with the United States IMPINJ (one of leading innovators for RFID) in the Catch-up strategy in technology. Each strategy has its pros and cons, which depends on the firm's capability, resources availability, and business context.

Besides the strategy, we can study tactic of the focal firms to enrich our framework. There are six components in the digitally charged products derived by Fleisch et al., (2015) [20] for IoT general business model:

- Physical Freemium: This component describes a physical asset that is sold together with a free digital service at no additional charge. Some percentage of customers will select premium charged services afterward.

- Digital Add-on: A physical asset is sold very inexpensively at a thin margin. Over time, the customer can purchase or activate any number of digital services with a higher margin.

- Digital lock-in: This refers to a sensor-based, digital handshake that is deployed to limit compatibility, prevent counterfeits, and ensure warranties.

- Product as Point of Sales: Physical products become sites of digital sales and marketing services. The customer consumes services directly at the product or indirectly via a smart phone and identification technology.

- Object Self-Service: This component refers to the ability of things to independently place orders on the Internet.

- Remote Usage and Condition Monitoring: "Smart" things can transmit data about their own status or their environment in real time. This makes it possible to detect errors preventatively and to monitor usage and the remaining inventory of consumables.

In fact, digital freemium is very common. An example is Apps, where digital asset are free at first, but customer may pay premium services afterward. All these components are the general tactics employed by most of the collaborators in the IoT ecosystem. 
Table 2. Categories of IoT strategy (Li, et al., 2012) [19].

\begin{tabular}{|c|c|c|c|}
\hline & & \multicolumn{2}{|c|}{ Industrial driving force } \\
\hline & & Market pull & Technology push \\
\hline \multirow{2}{*}{ Strategic intent } & Get-ahead & $\begin{array}{c}\text { Get-ahead strategy in market } \\
\text { Example: Haier }\end{array}$ & $\begin{array}{c}\text { Get-ahead strategy in technology } \\
\text { Example: Cinterion }\end{array}$ \\
\hline & Catch-up & $\begin{array}{l}\text { Catch-up strategy in market } \\
\text { Example: Local Supermarket }\end{array}$ & $\begin{array}{c}\text { Catch-up strategy in technology } \\
\text { Example: Junmp }\end{array}$ \\
\hline
\end{tabular}

\subsection{Value Chain}

Value chains break down a firm's activities into a sequence of value-generating activities, starting from the conception and leading to end use. Value chains for IoT firms are more complicated than those of a traditional product; however the underlying concept remains the same. There are a least nine distinct product or service categories along the value chain in IoT in Table 3 (Raymond James Research, 2014) [21]. However, the report does not group the categories into different layers of architecture.

Holler et al., (2014) [1] posited a more detail information-driven value chain for IoT. There are four inputs, as depicted in Figure 5. Each of these four inputs undergo value addition through production/manufacture, processing, packaging, and then through distribution \& marketing as a finished product. The raw data are collected via different types of sensors, actuators, open data, operating or business system, and corporate database. It will undergo processing and packaging transmitted through a wireless of fixed network prior to becoming useful information. Because of the variety, velocity, and volume of this Big Data, infrastructure enablers and large scale system integrator are required. However, different players along the value chain have to overcome the interoperability issue as mentioned before. In reality, many successful players have been forced to vertically integrate a full solution of hardware, software, and service designed for a vertical market because of lack of standardization of connected devices and very little commonality between applications in different vertical market.

\subsection{Proposed Framework}

Building on the framework of Holler et al., (2014) [1], Iintegrate the IoT strategy category and value chain into the following framework in Table 4. A two-dimensional model replaces a three-dimensional one where monetary and/or non-monetary benefits are the value captured by the collaborators but not to the value nodes. We replace "Device" by "Input" since there are other types of input other than devices as shown in the IoT architecture. "Network" in IoT includes the "Production/Manufacturing" in the value chain. "Processing and Packaging" can be grouped under "Service". "Content" includes all the "Information Product". This grouping embraces all the layers proposed in Table 3 (Raymond James Research, 2014) [21], and Figure 2 (Chen Min, 2013) [15]. The value proposition of each collaborator along the value chain is then manifested in the table. A column specifying the category of IoT strategy (Table 2, Li et al., 2012) [19]: get-ahead strategy in market, catch-up strategy in market, get-ahead strategy in technology, and catch-up strategy in technology of each collaborator has been added. Furthermore, a column reveals the tactic derived by Fleisch et al., (2015) [20] has been included.

\section{Case Studies}

The qualitative analysis is based on multiple case studies which are adopted to explore the why, what, and how (Yin, Bateman, \& Moore, 1983) [22] essential elements of business model. A series of interviews with IoT Awardees, 2014 (Communications Association of Hong Kong Official Guide, 2015) [23], and the secondary data of the Best Smart Hong Kong Award Winner 2015

(http://download.hkictawards.hk/v_files/HKICTA/doc_2015/categories/Category_Award_Booklet/08_SH_Cate goryProgramme.pdf) were used to illustrate the proposed framework. A summary table for each company based on the proposed framework is shown below:

\subsection{Company: Hong Kong Communications Co., Ltd. (HKC) (http://www.hkc.com.hk/)}

Project description: Wong Tai Sin Temple is a popular tourist spot in Hong Kong, attracting more than 5 million 
Table 3. Various layers of the IoT value Chain (Raymond James Research, 2014) [21].

\begin{tabular}{ll}
\hline Radios & Chips that provide connectivity based on various radio protocols \\
Sensors & Chips that can measure various environmental/electrical variables \\
Microcontrollers & Processors/storage that allow low-cost intelligence on a chip \\
Modules & Combine radios, sensors, microcontrollers in a single package \\
Platform Software & Software that activates, monitors, analyzes device network \\
Application Software & Presents information in usable/analyzable format for end user \\
Device & Integrates modules with app software into a usable form factor \\
Airtime & Use of licensed or unlicensed spectrum for communications \\
Service & Deploying/Managing/Supporting IoT solution
\end{tabular}

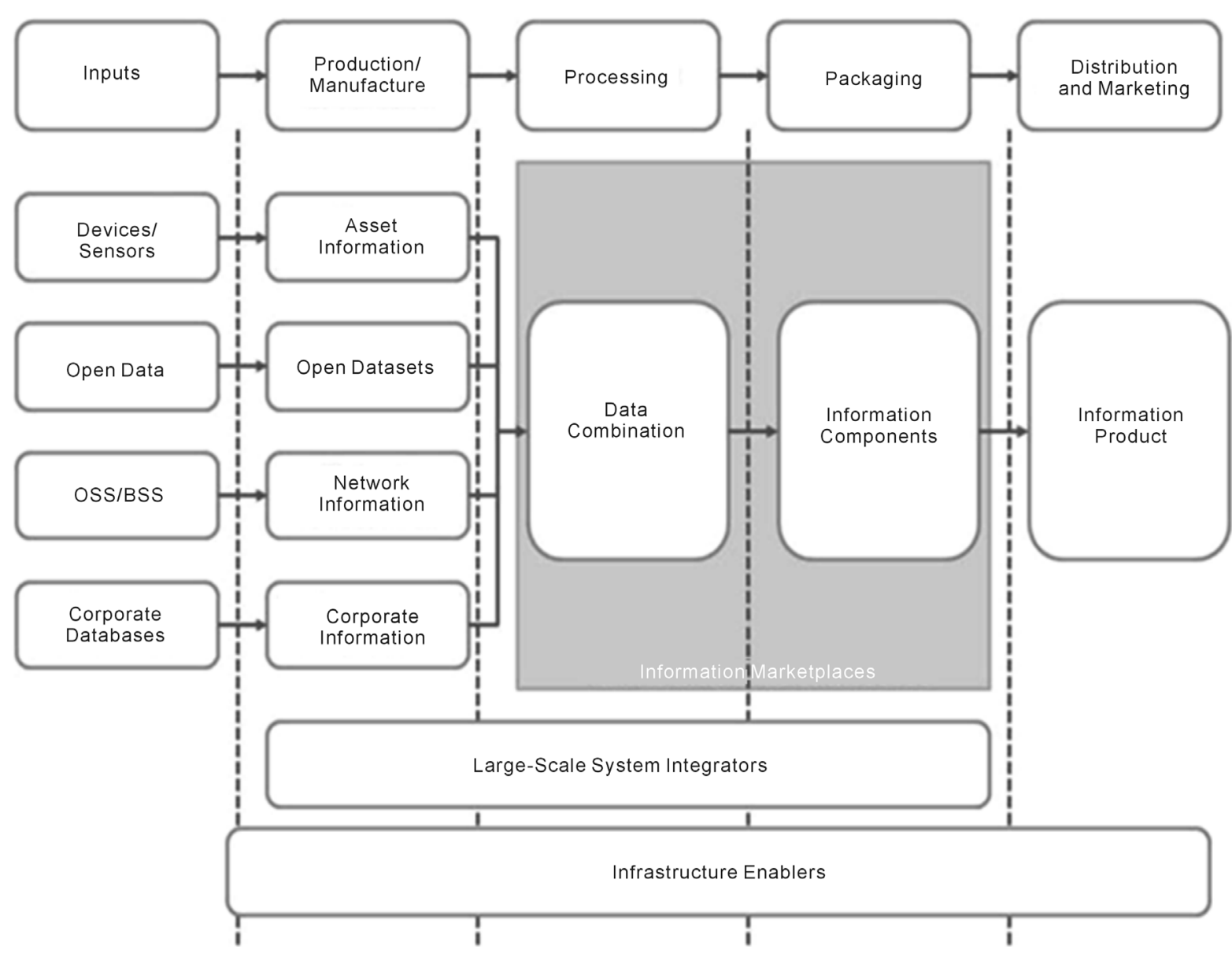

Figure 5. Information-driven value chain for IoT (Holler et al., 2014) [1].

Table 4. Proposed IoT business model framework.

\begin{tabular}{ccccc}
\hline Company Collaborator Inputs Network & $\begin{array}{c}\text { Service/ } \\
\text { processing/ } \\
\text { packaging }\end{array}$ & $\begin{array}{c}\text { Content/ } \\
\text { Information } \\
\text { product }\end{array}$ Benefits Strategy Tactic \\
ABC & C1 2 & & \\
\hline
\end{tabular}


visitors per annum. However, during the crowded peak seasons, the information board that contains detailed information about the cultures and stories of Temple becomes inaccessible to many visitors. Due to the absence of effective communication platform between Temple and visitors, the Management was unable to estimate the number of visitor during peak seasons and couldn't allocate enough manpower to handle the huge number of visitors. With reference to the real time object tracking approach, the project leveraged on the existing WiFi network in Wong Tai Sin Temple, as well as the real time location tracking system platform and mobile application, to develop a free mobile app for tourists, providing self-serving tour guide services. With the free mobile app, they now can access introductory video and information at each attraction point without the assistance of tourist guides.

Product/service: Real time location tracking system (RTLS) with an App to be downloaded by visitor:

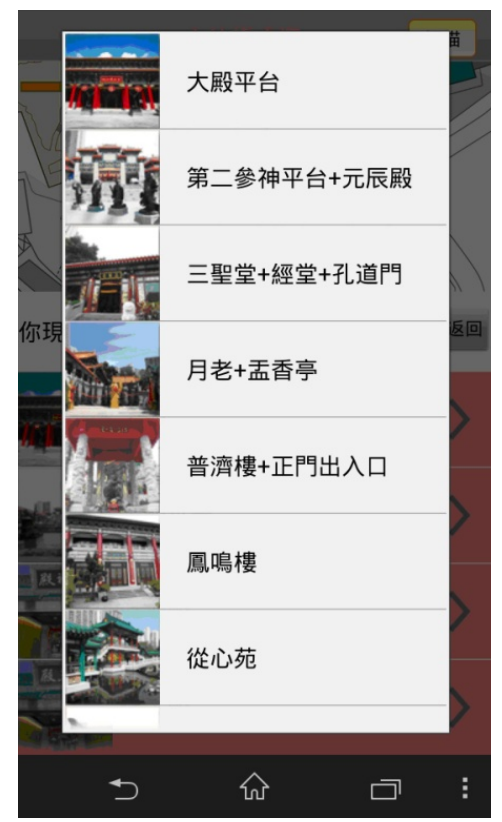

The GUI appeared on a smart phone

\begin{tabular}{|c|c|c|c|c|c|c|c|}
\hline Collaborator & Inputs & Network & $\begin{array}{c}\text { Service/ } \\
\text { processing/ } \\
\text { packaging }\end{array}$ & $\begin{array}{c}\text { Content/ } \\
\text { Information } \\
\text { product }\end{array}$ & Benefits & Strategy & Tactic \\
\hline Visitor & $\begin{array}{l}\text { Location via } \\
\text { an App at the } \\
\text { mobile phone }\end{array}$ & & & $\begin{array}{l}\text { Historical } \\
\text { information at } \\
\text { the mobile } \\
\text { phone }\end{array}$ & $\begin{array}{l}\text { Enrich } \\
\text { experience \& } \\
\text { promotion } \\
\text { coupons }\end{array}$ & & \\
\hline $\mathrm{HKC}$ & $\begin{array}{l}\text { Deployment } \\
\text { of a RTLS } \\
\text { system }\end{array}$ & & $\begin{array}{l}\text { User location by } \\
\text { an algorithm } \\
\text { software in server, } \\
\text { \& an Apps for } \\
\text { user }\end{array}$ & $\begin{array}{l}\text { The WiFi } \\
\text { signal strength } \\
\text { received at } \\
\text { each mobile } \\
\text { phone }\end{array}$ & $\begin{array}{c}\text { Provide real } \\
\text { time location } \\
\text { system to client } \\
\text { with monetary } \\
\text { reward }\end{array}$ & $\begin{array}{l}\text { Catch-up } \\
\text { strategy in } \\
\text { technology }\end{array}$ & Digital lock-in \\
\hline $\begin{array}{l}\text { Client: Wong } \\
\text { Tai Sin } \\
\text { Temple }\end{array}$ & & $\begin{array}{l}\text { WiFi network } \\
\text { provided by } \\
\text { the Temple }\end{array}$ & $\begin{array}{l}\text { Push the historical } \\
\text { information to } \\
\text { visitor according } \\
\text { to their location. }\end{array}$ & $\begin{array}{c}\text { Number of } \\
\text { visitors at each } \\
\text { site }\end{array}$ & $\begin{array}{c}\text { Man-power } \\
\text { planning, \& } \\
\text { sales promotion }\end{array}$ & $\begin{array}{c}\text { Get-ahead } \\
\text { strategy in } \\
\text { market }\end{array}$ & $\begin{array}{c}\text { Product as Point } \\
\text { of Sales }\end{array}$ \\
\hline
\end{tabular}

\subsection{Company: Megabyte Ltd. (http://www.myndar.com/)}

Project description: Jewelry is one of the traditional industries in Hong Kong. Over the past decade, the whole industry has been growing rapidly due to the fast growing economy in Mainland China. However, many jewelry 
stores are still handwriting receipts, providing price information verbally and operating in the traditional business model. When the salespeople are showcasing diamond and jewelry to customers, they are required to keep a close eye on the jewelry and customers, thus they are not able to provide further information in order to make the deal. Megabyte Limited has developed a mobile retail tray, mTray, a smart display tray for jewelry running on Cloud. It is equipped with multiple wireless technologies, including RFID, NFC and Bluetooth and the solution reduces manual process and eliminates human errors.

Product/service: Mobile retail tray

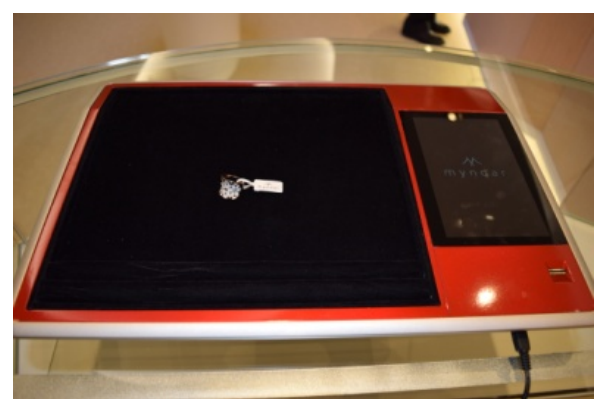

Based on Android platform, and with 50 patented designs, mTray perfectly integrates POS, security, price calculation and user survey functions in a single platform.

\begin{tabular}{|c|c|c|c|c|c|c|c|}
\hline Collaborator & Inputs & Network & $\begin{array}{l}\text { Service/ } \\
\text { processing/ } \\
\text { packaging }\end{array}$ & $\begin{array}{c}\text { Content/ } \\
\text { Information } \\
\text { product }\end{array}$ & Benefits & Strategy & Tactic \\
\hline Shopper & Mobile phone & NFC & & $\begin{array}{c}\text { Product } \\
\text { information }\end{array}$ & $\begin{array}{l}\text { Update information, } \\
\& \text { dedicated } \\
\text { customer service }\end{array}$ & & \\
\hline Megabyte & $\begin{array}{l}\text { RFID enable } \\
\text { mobile tray, \& } \\
\text { tags attached } \\
\text { to each jewel }\end{array}$ & $\begin{array}{l}\text { Cloud } \\
\text { service }\end{array}$ & $\begin{array}{l}\text { Movement of } \\
\text { each jewel on } \\
\text { the tray \& by } \\
\text { whom }\end{array}$ & $\begin{array}{l}\text { The popularity of } \\
\text { each jewel, customer } \\
\text { behavior, stock level }\end{array}$ & $\begin{array}{l}\text { To provide a RFID } \\
\text { portable tray for } \\
\text { retailer with } 50 \\
\text { patents }\end{array}$ & $\begin{array}{l}\text { Get-ahead } \\
\text { strategy in } \\
\text { technology }\end{array}$ & Digital lock-in \\
\hline Jewel retailer & $\begin{array}{c}\text { Salesman } \\
\text { fingerprint } \\
\text { authentication, } \\
\text { customer } \\
\text { profile }\end{array}$ & $\begin{array}{l}\text { RFID, } \\
\text { Bluetooth, } \\
\text { \& LAN }\end{array}$ & $\begin{array}{c}\text { Customer } \\
\text { preference, } \\
\text { salesmanship } \\
\text { improvement }\end{array}$ & $\begin{array}{l}\text { Location of each } \\
\text { jewel, sales data \& } \\
\text { product information } \\
\text { in cloud }\end{array}$ & $\begin{array}{l}\text { Security, pricing } \\
\text { update, customer } \\
\text { profile, stock take \& } \\
\text { POS integration }\end{array}$ & $\begin{array}{l}\text { Get-ahead } \\
\text { strategy in } \\
\text { market }\end{array}$ & $\begin{array}{l}\text { Remote usage } \\
\text { and condition } \\
\text { monitoring }\end{array}$ \\
\hline
\end{tabular}

\subsection{Company: Digimobil Technology Ltd. \& Rodsum Wireless Ltd. (http://www.gpsfinder.hk/, http://www.rodsum.com/)}

Project description: The building cost of Hong Kong-Zhuhai-Macao Bridge Project is as high as RMB76.2 billion and the progress is now in full swing. Since the construction is very close to the Hong Kong International Airport in Chek Lap Kok, the developers must efficiently control the heights of the construction machineries to prevent affecting the flight paths and causing danger. It is easier to control the heights on the land as compared with that at the sea because there are high and low tides at the sea, as well as the sailing vessels. The height restriction should meet the requirement from Civil Aviation Department; therefore, it is necessary to have a realtime monitoring system for precise height calculation. The system consists of 5 components, namely: GPS antenna, a master controller, sensor for measuring height and angle, Draught Senor, and an alarm system installed at different parts of the vessel. Together with the use of cloud server, if the height of the suspended platform of the engineering vessel exceeds the limit, the red light alarm will be turned on to remind the suspended platform operators to immediately lower the suspended platform back to the safe level. If the irregularities sustain, the system will automatically send messages and emails to alert the engineer manage and Civil Aviation Department.

Product/service: Equipment Height Real-time Monitoring System (EHRMS) for HK-Zhuhai Macao Bridge 
Project

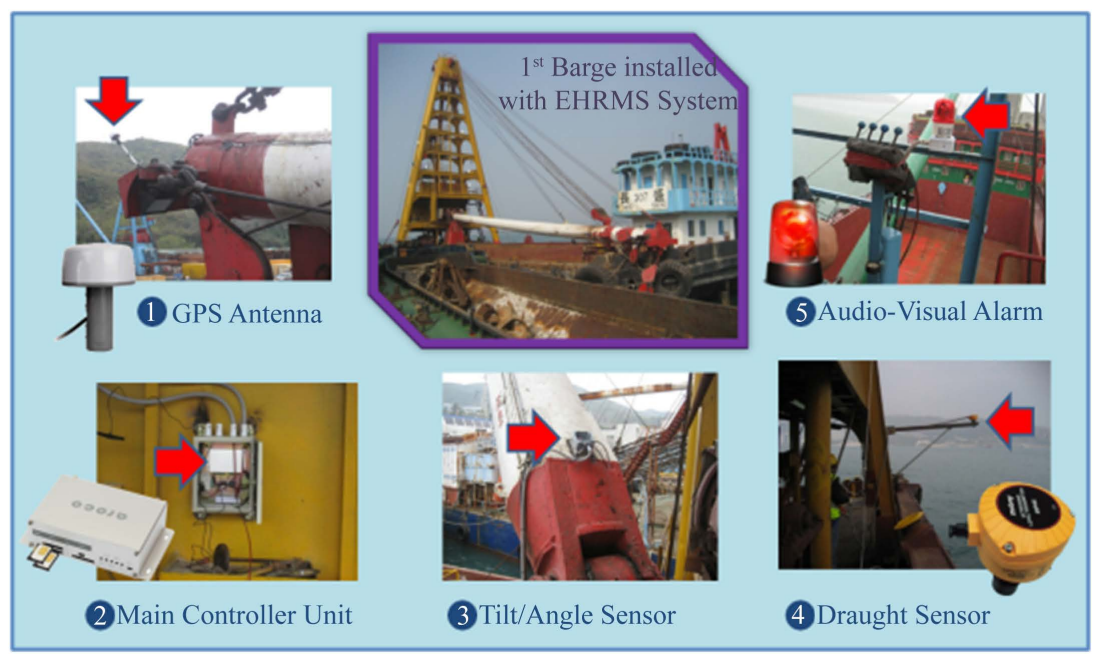

Once the sensor and the intranet device are installed on the suspended platform and working vessel, administrators and the government officers can monitor the height of the suspended platform anytime.

\begin{tabular}{|c|c|c|c|c|c|c|c|}
\hline Collaborator & Inputs & Network & $\begin{array}{c}\text { Service/ } \\
\text { processing/ } \\
\text { packaging }\end{array}$ & $\begin{array}{c}\text { Content/ } \\
\text { Information } \\
\text { product }\end{array}$ & Benefits & Strategy & Tactic \\
\hline $\begin{array}{l}\text { Construction } \\
\text { Boats }\end{array}$ & $\begin{array}{l}\text { GPS, height } \\
\text { \& angle } \\
\text { measurement } \\
\text { device, alert } \\
\text { system }\end{array}$ & & $\begin{array}{l}\text { Adjust the } \\
\text { construction arm } \\
\text { upon the receipt of } \\
\text { alarm }\end{array}$ & & Compliances & & \\
\hline $\begin{array}{l}\text { Digimobil \& } \\
\text { Rodsum }\end{array}$ & & $\begin{array}{c}\text { GSM, } \\
\text { Cloud } \\
\text { service }\end{array}$ & $\begin{array}{l}\text { Trigger the alert when } \\
\text { the construction arm } \\
\text { of the boat exceeds } \\
\text { the limit, SMS \& } \\
\text { email to the boat } \\
\text { Management }\end{array}$ & $\begin{array}{c}\text { GPS data, tide } \\
\text { data from } \\
\text { Observatory, } \\
\text { height limit from } \\
\text { Aviation Dept., } \\
\text { arm height \& } \\
\text { angle of each boat }\end{array}$ & $\begin{array}{l}\text { Monthly charge } \\
\text { for the height } \\
\text { monitoring for } \\
30 \text { construction } \\
\text { boats }\end{array}$ & $\begin{array}{l}\text { Get-ahead } \\
\text { strategy in } \\
\text { technology }\end{array}$ & $\begin{array}{l}\text { Digital add-on } \\
\quad \text { \& lock-in }\end{array}$ \\
\hline $\begin{array}{c}\text { Civil } \\
\text { Aviation } \\
\text { Department }\end{array}$ & & $\begin{array}{l}\text { Internet } \\
\text { access }\end{array}$ & & & $\begin{array}{c}\text { Safety } \\
\text { monitoring }\end{array}$ & $\begin{array}{c}\text { Get-ahead } \\
\text { strategy in } \\
\text { market }\end{array}$ & $\begin{array}{l}\text { Remote usage } \\
\text { and condition } \\
\text { monitoring }\end{array}$ \\
\hline
\end{tabular}

\subsection{Company: Axon Labs Ltd. (http://www.axon-labs.com/)}

Project description: HKBus+ is an information platform offering comprehensive public transportation information in Hong Kong, covering buses, mini-buses, MTR, ferries and trams. It combines the open data released by the HKSAR government as well as data collected from the Internet to offer the most comprehensive and upto-date information to the users. The app provides many useful and convenient functions, including intelligent search, point-to-point route search, nearby stops and stations, transit suggestions, taxi fare estimation, and some personalized functions such as favorite routes and destinations. The app will also notify the users via push messages about the latest updates of public transportation services and abnormal traffic conditions. Currently, HKBus+ is offered for free in app stores. The main source of revenue is from mobile advertisements. They are using Google's AdMob mobile ad services. Their collaborators in the ecosystem include:

Vpon: a company specialized in location-based mobile ads, to deliver mobile ads to their users. EasyVan: a popular van calling app in Hong Kong providing the estimated cost of calling a van.

Flytaxi: a popular taxi calling app in Hong Kong providing the estimated taxi fare when the user performs a 
point-to-point search.

Foodpanda: a mobile app that allow users to order food delivery easily. By using location-based technology, they recommend to the users restaurants that offer delivery services and are close to their current or home locations.

Product/service: Public Transport App

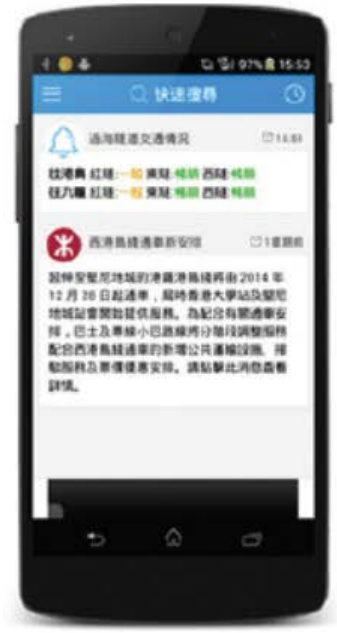

Latest traffic news

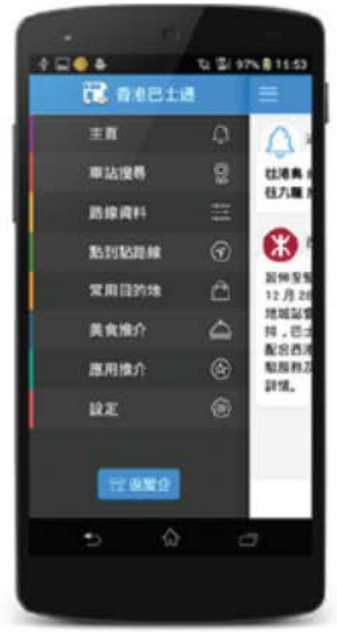

Functions route information
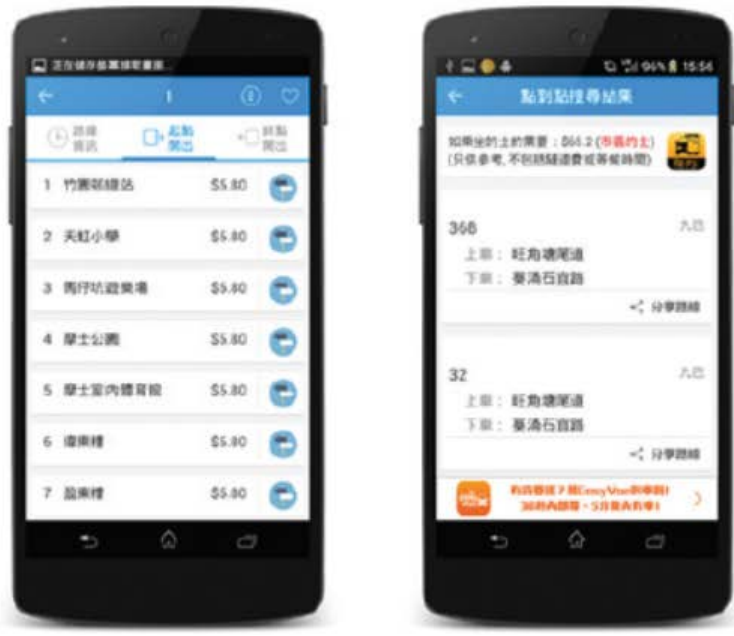

Point to point search

\begin{tabular}{|c|c|c|c|c|c|c|c|}
\hline Collaborator & Inputs & Network & $\begin{array}{c}\text { Service/ } \\
\text { processing/ } \\
\text { packaging }\end{array}$ & $\begin{array}{c}\text { Content/ } \\
\text { Information } \\
\text { product }\end{array}$ & Benefits & Strategy & Tactic \\
\hline User & $\begin{array}{l}\text { Destination at } \\
\text { the mobile App }\end{array}$ & Mobile network & & $\begin{array}{l}\text { Bus no, fee, bus } \\
\text { stops information }\end{array}$ & $\begin{array}{l}\text { Nearest bus } \\
\text { stop location, } \\
\text { latest traffic } \\
\text { conditions }\end{array}$ & & \\
\hline HKBus+ & $\begin{array}{c}\text { Public data from } \\
\text { the transportation } \\
\text { Companies, } \\
\text { Government } \\
\text { department, \& } \\
\text { user location }\end{array}$ & Internet & $\begin{array}{l}\text { Collect the data } \\
\text { \&repackaging }\end{array}$ & $\begin{array}{c}\text { Bus no } \\
\text { recommendation, } \\
\text { \& traffic } \\
\text { conditions }\end{array}$ & $\begin{array}{l}\text { Build up a } \\
\text { large customer } \\
\text { data base for } \\
\text { advertisement } \\
\text { \& other add-on } \\
\text { services }\end{array}$ & $\begin{array}{l}\text { Get-ahead } \\
\text { strategy in } \\
\text { technology }\end{array}$ & $\begin{array}{c}\text { Digital } \\
\text { freemium }\end{array}$ \\
\hline $\begin{array}{c}\text { Vpon, } \\
\text { EasyVan, } \\
\text { Flytaxi, } \\
\text { Foodpanda }\end{array}$ & User location & Mobile network & $\begin{array}{c}\text { Advertisement, } \\
\text { Van, taxi, food } \\
\text { delivery }\end{array}$ & $\begin{array}{c}\text { Availability, } \\
\text { arrival time, \& } \\
\text { fee }\end{array}$ & $\begin{array}{l}\text { Service } \\
\text { charges }\end{array}$ & $\begin{array}{c}\text { Ride on the } \\
\text { customer } \\
\text { base of } \\
\text { HKBus+ }\end{array}$ & $\begin{array}{c}\text { Product as } \\
\text { point of sales }\end{array}$ \\
\hline
\end{tabular}

\subsection{Company: Cenique Infotainment Group Limited (http://www.cenique.com/), Hutchison Global Communications Ltd. (www.hgc.com.hk)}

Project description: With the smart TV installed at the shopping mall, the camera on the TV can find out the effectiveness and ROI of digital signage and point-of-purchase displays through a Cloud Audience Analytics. It is a video "presence detection" solution providing shopper analytics about their profile such as gender, age, etc in real-time, automatically pop up the appropriate advertisement, collecting and reporting insightful information for improving advertising effectiveness. Cenique provides the analytic software and gateway, while Hutchison provides the mobile network and Cloud facility.

Product/Service: IntelliSense Analytics 


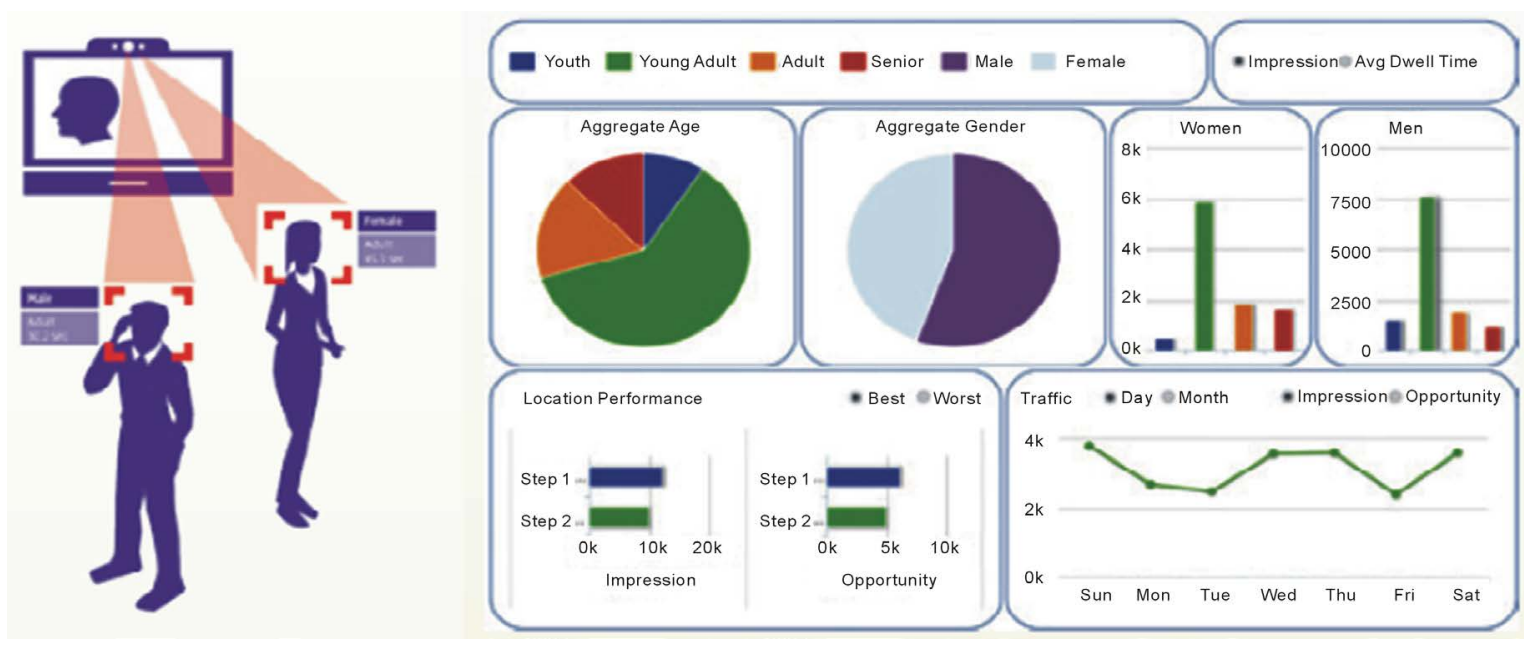

\begin{tabular}{|c|c|c|c|c|c|c|c|}
\hline Collaborator & Inputs & Network & $\begin{array}{l}\text { Service/ } \\
\text { processing/ } \\
\text { packaging }\end{array}$ & $\begin{array}{c}\text { Content/ } \\
\text { Information } \\
\text { product }\end{array}$ & Benefits & Strategy & Tactic \\
\hline Advertiser & $\begin{array}{l}\text { Advertising } \\
\text { message }\end{array}$ & & & $\begin{array}{l}\text { Product \& } \\
\text { promotion } \\
\text { information }\end{array}$ & $\begin{array}{c}\text { Viewer profile, } \\
\text { ROI \& } \\
\text { effectiveness of } \\
\text { the advertisement }\end{array}$ & $\begin{array}{l}\text { Get-ahead } \\
\text { strategy in } \\
\text { market }\end{array}$ & $\begin{array}{l}\text { Target customer } \\
\text { information } \\
\text { pushing }\end{array}$ \\
\hline Hutchison & $\begin{array}{c}\text { Digital signage } \\
\text { with camera\& } \\
\text { transmission } \\
\text { modem. }\end{array}$ & $\begin{array}{l}\text { Mobile } \\
\text { network }\end{array}$ & $\begin{array}{l}\text { Cloud } \\
\text { service }\end{array}$ & $\begin{array}{l}\text { Pop up appropriate } \\
\text { Advertisement } \\
\text { according to the } \\
\text { viewer's profile }\end{array}$ & $\begin{array}{l}\text { Cloud service } \\
\text { platform }\end{array}$ & $\begin{array}{c}\text { Get-ahead } \\
\text { strategy in } \\
\text { technology \& } \\
\text { market }\end{array}$ & $\begin{array}{l}\text { Product as point } \\
\text { of sales }\end{array}$ \\
\hline Cenique & Viewer's image & & $\begin{array}{l}\text { Data } \\
\text { analytic }\end{array}$ & Viewer's profile & Service charges & $\begin{array}{l}\text { Get-ahead } \\
\text { strategy in } \\
\text { technology }\end{array}$ & $\begin{array}{l}\text { Remote usage } \\
\text { and condition } \\
\text { monitoring }\end{array}$ \\
\hline
\end{tabular}

\subsection{Company: Fukui Shell Nucleus Factory (http://www.fukuishell.com/)}

Project description: Unlike diamonds and gemstones which can now be sold online with confidence and have their own internationally recognized standards, the pearl industry is facing the challenges of identity, trackand-traceability, and authentication. Each pearl nucleus is embedded with a RFID tag, registered by technology called Metakaku. By adding in data and information to the database along the cultivation period, each pearl shall have a record that tells its unique story about the pearl's true origin, cultivation period and its current whereabouts. The RFID tag contains a unique Electronic Product Code (EPC) serial number via a unique serialization and the track-and-trace function provided by GS1, a non-profit organization, industry-led global supply chain standards organization. A high level authentication with a dynamic security key is done by a technology called AuthenTick ${ }^{\mathrm{TM}}$ developed by theHong Kong R\&D Centre for Logistics and Supply Chain Management (LSCM). The information is collected collaboratively throughout the value chain is then stored in the database called the Global Pearl Database (GPD) developed by LSCM as well. The pearl enquirer can access the information by using the pearl search engine that is powered by the GS1's Search Directory and the GPD's information.

Product/Service: MetakakuTM, the technological enabler that allows unique identification for each pearl.

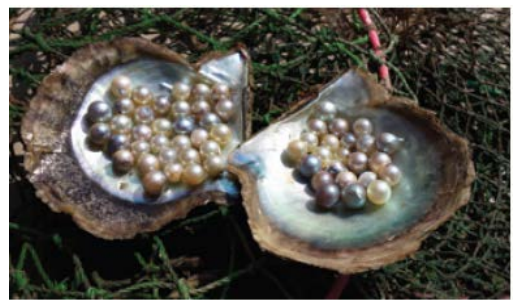




\begin{tabular}{|c|c|c|c|c|c|c|c|}
\hline Collaborator & Inputs & Network & $\begin{array}{l}\text { Service/ } \\
\text { processing/ } \\
\text { packaging }\end{array}$ & $\begin{array}{c}\text { Content/ } \\
\text { Information } \\
\text { product }\end{array}$ & Benefits & Strategy & Tactic \\
\hline Fukui & RFID tag & & $\begin{array}{l}\text { Pearl nucleus } \\
\text { embedded with } \\
\text { RFID tag }\end{array}$ & $\begin{array}{c}\text { Identity, } \\
\text { track-and-traceability, } \\
\text { and authentication }\end{array}$ & $\begin{array}{l}\text { Technology } \\
\text { enabler }\end{array}$ & $\begin{array}{l}\text { Get-ahead } \\
\text { strategy in } \\
\text { technology }\end{array}$ & $\begin{array}{l}\text { Increase product } \\
\text { value via IoT } \\
\text { benefit }\end{array}$ \\
\hline GS1 & & Internet & $\begin{array}{l}\text { EPCIS (electronic } \\
\text { product code } \\
\text { information } \\
\text { service) \& Search } \\
\text { Directory }\end{array}$ & $\begin{array}{l}\text { A unique serialization } \\
\text { of the numbers for } \\
\text { Metakaku, \& } \\
\text { searching function }\end{array}$ & $\begin{array}{l}\text { Service } \\
\text { platform }\end{array}$ & $\begin{array}{l}\text { Get-ahead } \\
\text { strategy in } \\
\text { technology }\end{array}$ & $\begin{array}{c}\text { Remote usage } \\
\text { and condition } \\
\text { monitoring }\end{array}$ \\
\hline LSCM & & Internet & $\begin{array}{c}\text { AuthenTick \& } \\
\text { Global Pearl } \\
\text { Database (GPD) }\end{array}$ & $\begin{array}{l}\text { Data collected } \\
\text { throughout the value } \\
\text { chain }\end{array}$ & $\begin{array}{l}\text { Service } \\
\text { platform }\end{array}$ & $\begin{array}{l}\text { Get-ahead } \\
\text { strategy in } \\
\text { technology }\end{array}$ & $\begin{array}{c}\text { Remote usage } \\
\text { and condition } \\
\text { monitoring }\end{array}$ \\
\hline $\begin{array}{l}\text { Pearl } \\
\text { enquirer }\end{array}$ & $\begin{array}{c}\text { Pearl } \\
\text { information } \\
\text { via a RFID } \\
\text { scanner }\end{array}$ & Internet & & $\begin{array}{l}\text { Authentication \& } \\
\text { product information }\end{array}$ & $\begin{array}{l}\text { Product } \\
\text { confidence }\end{array}$ & & \\
\hline
\end{tabular}

\section{Discussion and Summary}

In the business model framework proposed by Turber et al., (2014) [6], the context of the Internet of Things is based on service-dominant logic. This "who, where, and why" framework clearly shows that in the IoT, the firms are not the only ones producing value for the customers to buy, but rather all collaborators have some role in the production of value. As shown in our framework above, all the collaborators have their own indispensible role in its IoT ecosystem. With Reference is made to Figure 2 about the architecture of IoT, I summarize the involvement of each focal Company into each layer.

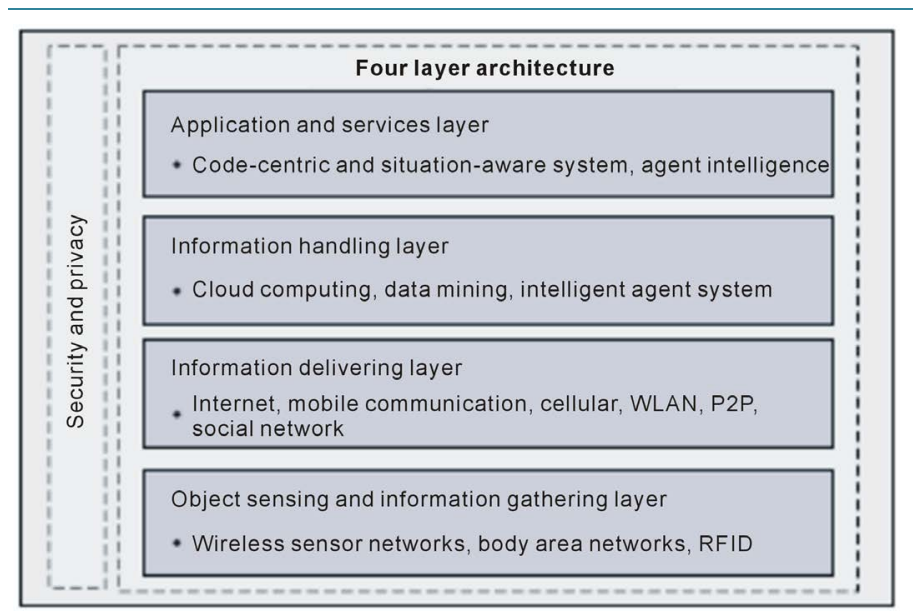

Focal Company

Digimobil Technology Ltd. \& Rodsum Wireless Ltd.; Megabyte Ltd.; HKC; Axon Labs Ltd.; Cenique; Fukui

Digimobil Technology Ltd. \& Rodsum Wireless Ltd.; Megabyte Ltd.; Hutchison; Cenique

Hutchison

Digimobil Technology Ltd. \& Rodsum Wireless Ltd.; Megabyte Ltd.; HKC; Cenique; Fukui

Solution providers like HKC, and Megabyte involve sensors, information handling, and application layers. Their services like augmented system integration with customization and software development. The after sales services can be augmented because the system status can be monitored \& diagnosed remotely. Fukui worked with a technology enabler to apply RFID in their specific industry, and collaborated with several parties in the Ecosystem. They can extend the service to the whole industry and become a platform business. Axon labs provided a free App for download to build up a customer base first before any value capture. It invited several other related service providers to create synergy. This is a typical digital freemium business model. Cenique provides viewer profile analytic riding on the Cloud service provided by Hutchison. Their services can provide a direct target advertising platform for the merchants. Digimobil Technology and Rodsum Wireless extend the ownership model from the user to the service through access to product data and the ability to monitor the performance 
of the installed devices. Customer can even enjoy the model of "Pay as you go" or "Product as a Service” instead of a huge upfront payment. A hybrid model between a conventional customer ownership and product-asa-service, such as product sales bundled with service contract, or product sales bundled with performance based contract has been manifested. Almost all the cases are running on a close system to which third party taking over is difficult. Tremendous effort is required to learn the Industry domain, customization, and implementation. Through all these case studies, it showed that the benefits of the collaborators are a great leap in operation efficiency, productivity, a strengthening in customer services, and new revenue streams.

Although the sample size is not big, the studies included user, vendor, system integration, and solution and service providers, while the applications are cross industries, thus the observations, and the lessons from the interviews are quite conclusive:

1) The technology breakthrough in miniaturization, energy efficiency of sensors enables a lot of portable devices, and thus convenient and real time IoT applications.

2) The development \& deployment process is quite long or have gone through a Proof of Concept stage as there is no precedent in most of the applications. The advantage for the incumbents is high entry barrier if they can sustain the initial investment period.

3) Affordable wireless connectivity provides ubiquitous network connection for IoT devices.

4) As Cloud service is widely employed in most applications, it creates a common data storage platform for collaborators.

5) Sometimes external information is required in additional to the sensor data for holistic analysis. Some of these are open data such weather, traffic, and geo-mapping.

6) Integration with client back-end system is required in most cases.

7) All the developers/Integrators adopted either a get-ahead strategy in technology or get-ahead strategy in market while the clients mostly adopted a get-ahead strategy in market. The clients must buy in the idea, and the product/solution providers must accommodate more late-stage and post purchase design changes for the fine tuning after initial implementation.

8) The common tactics are digital or physical freemium, Product as Point of Sales, and Remote Usage and Condition Monitoring.

9) IoT applications may involve a lot of different appliances/devices with different control protocol.

10) After-sales services can be much more efficient compared with traditional system because of the internet connected nature of IoT. It can also share the workload of individual device through system optimization.

11) IoT adoption is not reaching a mass market yet; the network effect is confined to specific vertical market because a lot of customization, and thus the domain knowledge are required.

12) Retailers demonstrate the strengthening of customer relationships, marketing, and security through the adoption of IoT.

13) Although an open system which facilities connection to other devices through an open interface or API is feasible, closed system which aims to have customer purchase the whole system from a chosen solution provider is preferable.

14) The performance of the product shifts from the functionality of a discrete product to that of a broader system which consists of the connection network, data storage, system data analytics, and integration with the existing backend management system.

With a rapidly growing industry and huge potential revenue over the horizon, companies can see the great potential in the IoT but struggle on how to approach it. Not much data exists on how business operates within an IoT context, and so companies are reluctant to take the big leap into the IoT. Just as soon as the business potential was realized, so was the need for network-centric IoT business model framework. This article addresses this issue by revealing the successful business models of the IoT Awardees. With that, we also testified that the value proposition, knowledge requirement, and thus the competitive advantages have been changing in the supply side while a new era of IT-driven productivity growth is emerging in the demand side.

\section{Limitations and Future Research}

Pure sensors manufacturers or technology enablers are excluded in this study because I mainly focus on those businesses involving more than one collaborators or solution base to validate the proposed business model framework. The case studies are mainly from businesses in Hong Kong. Future study can be extended to other 
cities with different contexts. Although some of these case studies involve data analytic, the self learn artificial intelligence application is not fully demonstrated. As the artificial intelligence or machine learning is indispensable in IoT applications, its impact on business model is a worthwhile topic for future research.

\section{References}

[1] Holler, J., Tsiatsis, V., Mulligan, C., Avesand, S., Karnouskos, S. and Boyle, D. (2014) From Machine-to-Machine to the Internet of Things: Introduction to a New Age of Intelligence. Elsevier, Waltham.

[2] Abdmeziem, R. and Tandjaoui, D. (2014) Internet of Things: Concept, Building blocks, Applications and Challenges, 28 January 2014, 1-17.

[3] GSMA (2014) From Concept to Delivery: The M2M Market Today. GSMA Intelligence, February, 3.

[4] Gubbi, J., Buyya, R., Marusic, S. and Palaniswami, M. (2013) Internet of Things (IoT): A Vision, Architectural Elements, and Future Directions, Future Generation Computer Systems, 29, 1645-1660. http://dx.doi.org/10.1016/j.future.2013.01.010

[5] Yoo, Y., Lyytinen, K.J., Jr. Boland, R.J. and Berente, N. (2010) The Next Wave of Digital Innovation: Opportunities and Challenges: A Report on the Research Workshop “Digital Challenges in Innovation Research”. Social Science Research Network, 1-37.

[6] Turber, S., Brocke, J.V., Gassmann, O. and Flesich, E. (2014) Designing Business Models in the Era of Internet of Things. 9th International Conference, DESRIST 2014, Miami, 22-24 May 2014, 17-31. http://dx.doi.org/10.1007/978-3-319-06701-8_2

[7] Atzori, L., Iera, A. and Morabito, G. (2014) From "Smart Objects” to "Social Objects”: The Next Evolutionary Step of the Internet of Things, IEEE Communications Magazine, 97-105. http://dx.doi.org/10.1109/MCOM.2014.6710070

[8] Business Model (2014) In Investopedia. http://www.investopedia.com/terms/b/businessmodel.asp

[9] Sun, Y., Yan, H., Lu, C., Bie, R. and Thomas, P. (2012) A Holistic Approach to Visualizing Business Models for the Internet of Things. Communications in Mobile Computing, 1, 1-7. http://dx.doi.org/10.1186/2192-1121-1-4

[10] Bucherer, E., Eisert, U. and Gassmann, O. (2012) Towards Systematic Business Model Innovation: Lessons from Product Innovation Management. Creativity and Innovation Management, 21, 183-198. http://dx.doi.org/10.1111/j.1467-8691.2012.00637.x

[11] Westerlund, M., Leminen, S. and Rajahonka, M. (2014) Designing Business Models for the Internet of Things. Technology Innovation Management Review, 4, 5-14.

[12] Gassmann, O., Frankenberger, K. and Csik, M. (2014) Revolutionizing the Business Model. In: Gassmann, O. and Schweitzer, F., Eds., Management of the Fuzzy Front End of Innovation, Springer, New York, 89-98. http://dx.doi.org/10.1007/978-3-319-01056-4_7

[13] Hui, G. (2014) How the Internet of Things Changes Business Models. Harvard Business Review.

[14] Mejtoft, T. (2011) Internet of Things and Co-Creation of Value. Proceedings of the 2011 International Conference on and 4th International Conference on Cyber, Physical and Social Computing, Dalian, 19-22 October 2011, 672-677. http://dx.doi.org/10.1109/iThings/CPSCom.2011.75

[15] Chen, M. (2013) Towards Smart City: M2M Communications with Software Agent Intelligence. Multimedia Tools and Applications, 67, 167-178.

[16] Leminen, S., Westerlund, M., Rajahonka, M. and Siuruainen, R. (2012) Towards IOT Ecosystems and Business Models. In: Andreev, S., Balandin, S. and Koucheryavy, Y., Eds., Internet of Things, Smart Spaces, and Next Generation Networking, 7469, Springer, Heidelberg, 15-26.

[17] Rong, K., Hu, G.Y., Lin, Y., Shi, Y.J. and Guo, L. (2015) Understanding Business Ecosystem Using a 6C Framework in Internet-of-Things-Based Sectors. International Journal of Production Economics, 159, 41-55. http://dx.doi.org/10.1016/j.ijpe.2014.09.003

[18] Kindstrom, D. (2010) Towards a Service-Based Business Model—Key Aspects for Future Competitive Advantage. European Management Journal, 28, 479-490.

[19] Li, Y., Hou, M.J., Liu, H. and Liu, Y. (2012) Towards a Theoretical Framework of Strategic Decision, Supporting Capability and Information Sharing under the Context of Internet of Things. Information Technology and Management, 13, 205-216. http://dx.doi.org/10.1007/s10799-012-0121-1

[20] Fleisch, E., Weinberger, M. and Wortmann, F. (2015) Business Models and the Internet of Things. In: Ivana, P.Z., Krešimir, P. and Martin, S., Eds., Interoperability and Open-Source Solutions for the Internet of Things, 9001, Springer, Berlin, 6-10.

[21] James, R. (2014) The Internet of Things: A study in Hype, Reality, Disruption, and Growth. Raymond James US Re- 
search, Technology \& Communications, Industry Report.

[22] Yin, R.K., Bateman, P.G. and Moore, G.B. (1983) Case Studies and Organizational Innovation: Strengthening the Connection. COSMOS Corporation, Washington DC.

[23] Communications Association of Hong Kong (2015) 2015 Official Guide to ICT Industry in Hong Kong, Theme: The Internet of Things. 60-91. 